\title{
The Exploration of China Discourse: From Anxiety over "Aphasia" to Innovation
}

\author{
Shunqing Cao*, Xiaojun Gao \\ Sichuan University, Chengdu, China \\ Email: ^shunqingcao@163.com,1970217476@qq.com
}

How to cite this paper: Cao, S. Q., \& Gao, X. J. (2017). The Exploration of China Discourse: From Anxiety over "Aphasia" to Innovation. Advances in Journalism and Communication, 5, 136-144. https://doi.org/10.4236/ajc.2017.52008

Received: May 31, 2017

Accepted: June 24, 2017

Published: June 28, 2017

Copyright $\odot 2017$ by authors and Scientific Research Publishing Inc. This work is licensed under the Creative Commons Attribution International License (CC BY 4.0).

http://creativecommons.org/licenses/by/4.0/

(c) (i) Open Access

\begin{abstract}
Contemporary Chinese literary theory is a discourse with Chinese characteristics. Yet for a while, as this discourse is marked with a pronounced "forgetting" of native traditions and a purposeful "misreading" of theories from the west, it has caused a sustained crisis over the identity of what Chinese literary theory highlighted by a deeply felt anxiety over "aphasia" - the loss of voice by Chinese scholars. The purpose of this research is to probe into the process of "China Discourse" from the lost to innovation and to find practical methods both for the theoretical construction and contemporary Chinese literary theories realizing a dialogue with the west under the background of cultural diversity. In the field of comparative literature, Variation Theory that put forth by Chinese comparatists represents the innovation of Chinese Discourse.
\end{abstract}

\section{Keywords}

Aphasia, China Discourse, Variation Theory, Contemporary Chinese Literary Theory, Western Literary Theory

\section{Introduction}

As China is becoming a great and powerful cultural force, there have been earnest efforts to assert the right for Chinese culture and literature to speak to the rest of the world communities. The original idea of this article derives from the reflection of Chinese literary and culture in the cultural pattern from single to polynary. The multiple coexistence, conflicts, dialogues and mutual development of culture deed provide us a valuable chance to recognize the relations between native literature and cultures outside, and to reconsider how to build up Chinese Discourse realizing its connection with modern society. Under such conditions, the existence and construction of Chinese literary theories are unavoidable. Chinese scholars propose this concept which conforms to the demands for the 
development of the times, trying to find a place where Chinese values and western cultures can enter into a dialogue of idea exchanges equally. In the discussion of China Discourse, we mainly focus on contemporary Chinese literary theories which play a crucial role in connecting tradition and modernization. The promotion of Chinese literary theories calls for traditional cultures as a strong support and modernity with Chinese characteristics in the real modern landscape to realize blossom.

\section{The Anxiety over "Aphasia" in China Discourse}

Even before the feeling of "aphasia" was verbalized by Chinese scholars, some of them had already realized the severe crisis that "China has no theory". From the First Emperor of Qin to the succeeding dynastic changes, Chinese traditional culture has undergone through many challenges. In modern times, tradition has been under attack from all sides in the name of modernization. And Chinese traditional literary theories and cultures are abandoned almost from "abolishing traditional ideology, cultures, customs and habits", "condemning Lin Biao and Confucius" in The Great Cultural Revolution during the 1966s to 1976s to the practice of the "down with the Confucianism" in order to attack traditional ideology in the May $4^{\text {th }}, 1919$. The harmful effects of slogans such as "Down with Confucianism" are given new consideration, as one scholar points out, it encourages people to "step on a wrong path of anti-feudalism. In other words, on a way of historical nihilism that denies Chinese ancient cultures from all sides" (Song, 1992). After Chinese scholar Chen Zhongfan published History of Chinese Literary Criticism in 1927, many authors follow the pattern of using western systematic and logical approaches to reclassify, define, and interpret ancient Chinese literary theories, such as Fang Xiaoyue's Chinese Literary Criticism (1934), Guo Shaoyu's History of Chinese Literary Criticism (1934), Luo Genze's History of Chinese Literary Criticism (1943) etc. Volumes of history of Chinese literary criticisms and literature theories travel on the road of westernization, deviating from the internal logic and features of Chinese ancient literary theories.

With the rapid development of technology and economy in the twentieth century, which are global by nature, cultural integration has become more self-conscious. Isolated and single regional cultural traditions are challenged, but more inclusive, polynary cultural models are encouraged. Both developing Eastern countries and developed countries are going through an enormous transformation from tradition to modernization, from single culture to multi-culture. During this era, the conflicts of different cultural systems are unavoidable. Throughout the process of Chinese literary theories in cultural fusion in the twentieth century, various foreign literary theories and ideological trends such as Russian literary theories, classical and modern western literary theories including structuralism, formalism, hermeneutics, phenomenology, new criticism, new historicism, deconstruction, post-colonialism flow over into circles of Chinese contemporary literature, overshadowing Chinese literary theories. For some 
time, people are "looking for a new sound in a foreign country" to energize native literary theories.

Anxiety rises within this trend immediately, however. A number of scholars start to question China's "modern culture identity" and "the literary foreignization of Chinese culture" (Zhou, 2006). They are unhappy that Chinese literary theories have followed western theories excessively and abandoned traditional literary theories, and they begin to explore effective ways for Chinese literary theories to realize dialogues between ancient and modern literary theories ac. For instance, Tong Qingbing comes up with three principles including historical priority, communication and self-consistency while trying to re-activate communication and practical significance in Chinese ancient literary theories. Cao Shunqing advocates realizing the sinicization of Chinese ancient literary theories and western literary theories, using native academic discourse rules to realize modern transformation for ancient literary theories, then applying to contemporary literature's criticism and creation. Zhang Jiang believes that the most essential task in Chinese contemporary literature theories is to "recheck the inverted relationship between theory and practice for a long time, abandon overdependent of exotic transcendental theories, and change the points of interest from chasing western theories to literary practice (Zhang, 2014). In addition, some argue the so-called "aphasia" is in fact part of a process of "language reconstruction" because Chinese theory of literature and art as a modern discipline has gone through similar experience the three times it tried to define itself. Some think the real meaning of "aphasia" does not mean we have no speech or only use western speech. On the contrary, it depends on "whether a new theory or new knowledge can be put forward" (Jiang, 2005). In my view, the discussion about "aphasia" of Chinese literary theories signifies multiple meanings and issues, such as nativism vs. westernization, tradition vs. modernization, and monolingualism vs. translated terms. It is ultimately the reflection of a desire for the construction of a Chinese discourse of theory and an anxiety over "aphasia" of intellectual subjectivity.

In The Anxiety of Influence: A Theory of Poetry, the famous American scholar Harold Bloom puts forward a bold thesis about poetic creation that the strong poets all live in the shadows of John Milton since the eighteenth century. And the later poets achieve a breakthrough by "killing", "misreading" and amending arguments of former poets intentionally. Bloom builds his new theories in the course of overturning and misreading the classics, and he also offers six "revisionary ratios" including "clinamen", "tessera", "kenosis", "daemonization", "askesis" and "apophrades" as the forms of productive "creative misreading."

The intellectual patterns that Bloom illuminates what has happened with Chinese literary theory in present-day China. In some way, traditional literature is "killed" simultaneously as western literary theories are "misread," yet the prosperity of Chinese literature and theory has not taken place. The result is a general feeling of "aphasia" as the shadow of the west still looms large in China's 
literary landscape.

Without question, with the change of literary experience and historical context, it is inappropriate to just simply copy native literary traditions in their various forms to build up Chinese contemporary literary theories. Chinese traditional literary theories have their epochal and historical features unable to represent current social mentality and changing ideologies. It is clear that many theoretical categories and propositions in classical poetics and literary theories are not equipped to explain complex literary practices of our day. On the other hand, western literary theories have their own historical and cultural limits and their rationality and feasibility remain untested in our local literary experiences.

Even though contemporary western literary theories indeed provided inspiration for Chinese literary theories in the transitional period of late $20^{\text {th }}$ century, but their deficiencies are apparent in the $21^{\text {th }}$ century. As one scholar points out, "western theories are generally departed from real literary practice, and too ready to borrow theories from other disciplines bear down on literary texts and literary experience, from which quick abstraction or generalization take the form of universal theory of literature" (Zhang, 2014). In some cases, western theories reverse the relationship between of theory and practice, favoring extreme positions and drifting from concept to concept without stable signified, a way of thinking is alien to the Chinese mind. For instance, New Criticism, famous for its advocacy of close reading and with the aim of opposing literary theories from Romanticism and social/historical criticism, had a strong influence in the United States in the 1940s and 1950s. Using its favorable subject of English poetry, New Criticism focuses on the text itself and literary devices such as metaphor and ambiguity in particular. New Criticism makes literature practices a reflection of literary theories, but it takes light of social, historical and cultural implications of the literary text. With the advance in cultural theory and culture studies, the limitation of New Criticism and closed textual studies of literature has been fully exposed. New Historicism, popular in the American academia in 1980's, could be seen as a natural correction of New Criticism. Compared with New Criticism, New Historicism pays more attention on the objectivity of literary text, and employs culture, history, and other elements to determine the meaning of the text. In its opposition to New Criticism, however, New Historicism commits its own excess by proposing a text is the product of culture, with a diminished view on the function of the writer and the reader.

It can be seen that some contemporary western literary theories came into being from criticizing their predecessors. It is a criticism necessary for opening up new space for innovation and invention. The way for contemporary western scholars to build new theories is to question and to attack certain problems in preceding theories, and then to propose bold arguments to be different. Maybe they are too hurried and too eager, because they often ignore shortcomings in their own theories, which fail to withstand a close scrutiny. Born out of western culture and the sublation of western tradition, western literary theories are not the only truth and should not be as such by Chinese scholars. 


\section{Looking Back at "the Self" from the Perspective of "the Other"}

"We come to realize our existence by knowing ourselves and features of the world that surround us" (Zhang, 2005). In other words, we acquire knowledge via differentiating "the Self" and "the Other". In terms of contemporary Chinese literary theories, they can be regarded as a fusion of Chinese traditional literary theories, traditional and contemporary western literary theories. Thus, the innovation of contemporary Chinese literary theories ought to stand in a global and historical context, treating contemporary western literary theories as a reference. Firstly, make it clear that the essential differences between "the Self" which represents Chinese literary theories and "the Other" that symbolizes contemporary western literary theories. For literary theories in East and West have their distinctive language structures, aesthetic tastes, values and ways of thinking, so as we learn from "the Other", we are in the course of perfecting "the Self". Secondly, it is essential to clarify the differences between traditional and contemporary Chinese literary theories; the discourse of contemporary Chinese literary theories should build up on traditional classics and then realize modernization from the current context and rules of speaking. The modernization of literary theories is the core of our research, by learning from western literary theories and clarifying "the Self" and "the Other", we find the heterogeneity and uniqueness of native theoretical discourse and bring about change.

Chinese traditional cultures derive from the specific society, historical context, and influenced by multiple factors such as politic, economy and culture in certain times, so they "belong to politic" or "serve for politic"; their inner logic, ways of thinking, rules of speaking, aesthetic tastes and philosophical thoughts are formed by local discourse. Still, there are many delicate expressions in Chinese literary theories, such as "gaining the power of expression without writing one word", "emptiness and concreteness produce each other", "the few illuminate the many", "small words for big meaning" and so on. "Poetic Wisdom" is referred to as the crucial feature to summarize Chinese literary theories in general.

The expression of "poems express ideas" in The Yao Classics of Shang Shu in the Qin Dynasty in early period, Lao Zi, Zhuang Zi, Book of songs, Chu Ci, Preface to Mao Poetry which edited by Liu Xiang, Prologue of Ode on Two Capitals written by Ban Gu in the Han Dynasty. Liu Xie's The Literary Mind and the Carving of Dragons, Lu Ji's Wen Fu, Cao Pi's Classical Treatise: On Literary Writing, Zhong Rong's Critique of Poetry in the Southern and Northern Dynasties. Si Kong Tu's The Twenty-Four Moods of Poetry in the Tang Dynasty, Zhang Rong's Sui Han Tang Poetry Notes in the Song Dynasty, Yan Yu's Canglang Poetry Talks and so on. These poetic theories and aesthetic works follow the characteristics of poetry, philosophy and imagination in common. For a long time, an essential reason for using western literary theories such as romanticism, realism to interpret Chinese classics seems reasonable is romanticism and realism trends have been sinicized; they change the forms to adapt to native, just the 
same as localization of Buddhism.

At present, people are keen on chasing fashionable western cultures and throwing away our native classics. It causes a serious situation that some native literary theories and works are completely new for us to understand, they only rely on translation before reading. What's more, the loss of traditional literary theories has undermined the spirits of creation and national confidence. In the new period, new theories are required to inspire traditional Chinese literary theories in the crisis and the construction of literary theories; the "misused" contemporary western literary theories have permeated silently into the textures of Chinese cultures. They endow native literary theories with some exotic elements, logical systems, literary forms, and more vitally, they have presented an awareness of modernization and variation for contemporary Chinese literary theories. As literary theories in East and West are not alike in nature; the methods of interpreting Chinese classics with foreign literary theories compulsorily are harmful to the perception of Chinese literary theories and even block the flourish of Chinese Discourse.

Aiming at exploring the laws of nature, western cultures start with the chains of seeking knowledge-observation-keep asking-conclusion, and they are equipped with traits of systemic, scientific and rigorous. Up to now, some believe western literary theories are not an organic unity in the $20^{\text {th }}$ century, for they make up of kinds of knowledge patterns, following the potential order of "regularity-deregulation-crisis-revolution" (Han, 2016). From feminism, new criticism, new historicism, post-colonialism to boundless culture studies, and influenced by anti-essentialism and nihilism, western literary theories have fallen into the crisis of "post-theory", directing at deconstructing truth, essence and center.

Eastern and western literary theories which represent two kinds of discourses have their own strong points and weaknesses. If we advocate western literary theories and restrain Chinese literary theories overly, we will be trapped into cultural relativism and imperialism. Such as Hegel draws the partial conclusion that western alphabetic writings are superior to Chinese characters, this "Neocolonialism in culture" (Zhang, 1998) is not conductive to enter into dialogues between China and the west, much less for intercultural complementations.

Good news is that now Chinese academia notice translation and introduction for literary theories from the west pave the way for the promotion of contemporary Chinese literary theories to integrate with world literatures better. A number of scholars consider that literary practices should be rooted in the realistic context of native literature, such as "investigation of individual case in the text" is an available breakthrough point in the course of literary creation. Some believe our current task is to activate traditional concepts of Chinese literary theories and to discover Chinese and western keywords in comparative literature. On September $10^{\text {th }} 2016$, shanghai research academy held a meeting on comparative research of Chinese and western keywords. In the meeting, researchers put forward ideas of enlarging the scales of keywords in traditional Chinese literary theories, and analyzing literary theories from East and West in relevance, inter- 
community, and comparative ways. They realized the goal of research was not a simple comparison between similarities and differences, but a requirement for original context and practices of literary theories. After the discussion, they reached a consensus on adding the columns of keywords in Chinese and western literary theories, going on exploring the topic and supporting "the symbolic concepts with Chinese characters" (Zhou, 2016); an influential slogan of "Chinese Keyword School" is desirable among academia.

In my perspective, the research beginning with keywords is reasonable and feasible, for the issue itself represents a kind of vital breakthrough of discourse. From another point of view, the precondition of comparing keywords is comparability, while certain keywords of literary theories cannot be compared in China and the west, so it is a complicated task to carry on. To contemporary Chinese literary theories, they also should change the fixed thinking modes into "finding similarity in difference" and "discovering variety from the same", by reflecting "the Self" and absorbing experience and lessons from outside world. In the global context, bringing Chinese philosophy and aesthetics into Chinese literary theories just as we are inspired from western literary theories for their philosophy, aesthetics and the progress of literary schools.

As Engels puts it, if we isolate natural objects, processes, putting aside grand relations, we are not investigate them in a state of motion, but in a state of stillness. In the present-day, in the process of reflecting western literary theories and traditional Chinese literary theories, new connotations and essences of foreign cultures are gained for the construction of Chinese Discourse. As Chinese scholar Qian Zhongwen says contemporary Chinese literary theories should be equipped with modern characteristics and kinds of rational spirits for communications and dialogues crossing the borders.

\section{The Innovation in China Discourse: The Variation Theory of Comparative Literature}

As the multicultural era is coming, lots of western scholars embark on "panculture research"; they question the significance of comparative literature as a discipline for the "no compare". Some famous comparatists like Susan Bassnett, Spivak assert "comparative literature has been dead", Bernheimer considers that comparative literature has "anxiety factors", and Weisstein thinks in the role of a comparatist, our territories of research are enough, but we are suffering from symptoms for worrying about boundless studies. Peter Brooks doubts comparative literature itself "not perhaps as a discipline, but as a place for the very conceptualization of discipline as it is pertinent to literary study" (Bernheimer, 1995). Actually the argument about death of comparative literature signifies the dilemma of western comparative literature, reminding us of changing ideas from "seeking the same" to return to "literariness". This allegory also predicts that it is time to step over circles of western civilization to seek enlightenments from the East. In the global context, comparatists come to realize European literatures are just a part of comparative literature, they are getting rid of "European Centra- 
lizing", and turning eyes on China, Japan, India and other places.

The Variation Theory of comparative literature stands for the third phase of the development and a major breakthrough of the discipline. The theory includes four levels of variation studies as language, literary text, national image and literature domestication; the research fields are imagology, acception, medio-translatology, cultural filtration and literary misreading. As Chinese scholar Cao Shunqing points out, the core value of the study of Variation is the difference which is away from the ideas of homogeneity of the French School (Cao, 2013). Variation Theory brings "heterogeneity", "variability" into the comparability and effectively amends deficiencies for the subject. The theory which expands the range of discipline and limits boundless expanding do assists comparative literature to escape from the crisis of "extensive subjects" and "theoretical heat", and solves the current confusions of international comparative literature. At present, comparative literature is marching on the path of crossing heterogeneity in civilization. For the view of methodology, Variation Theory that offers an effective and available theoretical foundation fits in with the requirement of the development of the times. Besides, it is also a powerful response to Chinese Discourse for us to achieve innovation of national culture.

In an era of globalization, accompanied by the changes of political and economic patterns, multiculturalism, a new regional pattern of knowledge has been shaped. With the rising of the status of China, Chinese literatures and cultures have drawn keen attentions of western scholars. In terms of comparative literature search field, the patterns of knowledge ruled by "The French Hour" and "The American Hour" formerly are becoming to the patterns of transnational, interdisciplinary and cross-civilization; "Chinese School" is attracting attentions of academia across the globe.

As China is becoming a great cultural force, we desire a new discourse to demonstrate our national characteristics and spirits. In the field of comparative literature, the innovation theory of Chinese School shows the innovation of Chinese comparative literature and the appeal of international comparative literature. Chinese scholars are speaking actively and leading the international comparative literature academia. For instance, Chinese comparatist Zhang Longxi has been elected as President of International Comparative Literature Association in 2016, and the next "Olympics" of academia in comparative literature will be held in Shenzhen University in China in 2019. As Zhang says, it is "a remarkable sign for comparative literature entering a new era" (Zhang, 2016).

\section{Conclusion: The Development of China Discourse in the Future}

In a word, Chinese Discourse has undergone an arduous experience from anxiety over "aphasia" to innovation in comparative literature. The feeling of "aphasia" can be considered as a result which was influenced by the over exclusion of traditional Chinese literary theories and "misreading" of western literary theories. The recent rapid development of Chinese economy and politics has given 
reasons to promote Chinese culture to go to the world; in the field of comparative literature, Variation Theory which put forth by Chinese comparatists represents new patterns of inter-heterogeneity civilizations and an innovation in the Chinese Discourse.

It is worth noting that even though conflicts and miscommunications between East and West are increasingly frequent, national characters and uniqueness in literary theories are visible more than ever. The future of Chinese culture and civilization will depend on a continuous and equal dialogue between China and the west that negotiates between heterogeneity and difference in cultural values. The development of contemporary Chinese literary theories which stands for a connection with tradition and modernity should be based on maintaining a distinctive self from the perspective of the other, and then bring about changes in the future.

\section{References}

Bernheimer, C. (1995). Comparative Literature in the Age of Multiculturalism (p. 104). Baltimore, MD: The Johns Hopkins University Press.

Cao, S. Q. (2013). The Variation Theory of Comparative Literature (p. 108). Berlin: Springer-Verlag. https://doi.org/10.1007/978-3-642-34277-6

Han, Z. J. (2016). On the Heterogeneity of the Western Literary Theory and the Construction of Chinese Literary Theory. Nanjing Journal of Social Sciences, No. 5.

Jiang, Y. (2005). A Reflection on “Aphasia”. Literary Review, No. 2.

Song, Z. F. (1992). An Historical Investigation of "Down with Confucianism". Confucius Studies, No. 2.

Zhang, J. (2014). Identification of Issues Concerning Contemporary Western Literary Criticism-With Concurrent Reflections on the Reconstruction of Chinese Literary Criticism. Social Science in China, No. 5.

Zhang, L. X. (1998). The Tao and the Logos (p. 11). Chengdu: Sichuan Renmin Press.

Zhang, L. X. (2005). Chinese and Western Literary Studies (p. 9). Shanghai: Fudan University Press.

Zhang, L. X. (2016). The New Era of Comparative Literature. Comparative Literature in China, No. 4.

Zhou, Q. Q. (2016). Key Words as the Key to Obtaining Discourse Power: A Summary of the Conference on Chinese and Western Literary Theory Theoretical Key Words Comparative Studies. Journal of Graduate School of Chinese Academy of Social Science, No. 6 .

Zhou, X. (2006). Legitimacy Debates and Identity Crisis-In the Case of "Aphasia" in Chinese Modern Literary Theory and "Westernization" of Chinese Modern Poetry. Journal of Nanjing University, No. 5. 
Submit or recommend next manuscript to SCIRP and we will provide best service for you:

Accepting pre-submission inquiries through Email, Facebook, LinkedIn, Twitter, etc. A wide selection of journals (inclusive of 9 subjects, more than 200 journals)

Providing 24-hour high-quality service

User-friendly online submission system

Fair and swift peer-review system

Efficient typesetting and proofreading procedure

Display of the result of downloads and visits, as well as the number of cited articles Maximum dissemination of your research work

Submit your manuscript at: http://papersubmission.scirp.org/

Or contact ajc@scirp.org 